\title{
CARBON ISOTOPES IN TREE RINGS: CLIMATE AND THE SUESS EFFECT INTERFERENCES IN THE LAST 400 YEARS
}

\author{
Anna Pazdur ${ }^{1,2}$ - Toshio Nakamura ${ }^{3} \bullet$ Sławomira Pawełczyk $^{1} \bullet$ Jacek Pawlyta $^{1} \bullet$ \\ Natalia Piotrowska ${ }^{1}$ Andrzej Rakowski ${ }^{1,3} \bullet$ Barbara Sensuła $^{1} \bullet$ Małgorzata Szczepanek $^{1}$
}

\begin{abstract}
New records of $\delta^{13} \mathrm{C}$ and $\Delta^{14} \mathrm{C}$ values in annual rings of pine and oak from different sites around the world were obtained with a time resolution of $1 \mathrm{yr}$. The results obtained for Europe (Poland), east Asia (Japan), and South America (Peru) are presented in this paper. The $\delta^{13} \mathrm{C}$ and radiocarbon concentration of $\alpha$-cellulose from annual tree rings of pine and of the latewood of oak were measured by both accelerator mass spectrometry (AMS) and liquid scintillation spectrometry (LSC). The values of ${ }^{14} \mathrm{~S}$, which represent decreasing ${ }^{14} \mathrm{C}$ concentrations caused by the emission of $\mathrm{CO}_{2}$ from fossil fuel use (Suess effect; Suess 1955), were calculated for each site. Low average ${ }^{14} \mathrm{~S}$ (about -0.4 to $0.8 \%$ ) values for clean areas and high values (about 3.4-3.6\%) for industrial and/or urbanized areas were noted. Records of the $\delta^{13} \mathrm{C}$ values obtained for pine and oak from Poland were used to reconstruct climate changes during the last $400 \mathrm{yr}$. The results clearly indicate the climate cooling during the periods of the Maunder minimum (1645-1715) and the Dalton minimum (1790-1820). The anti-correlation between the $\delta^{13} \mathrm{C}$ and $\Delta^{14} \mathrm{C}$ records during those 2 periods is clear if the ${ }^{14} \mathrm{C}$ record is shifted toward older ages by $24 \mathrm{yr}$.
\end{abstract}

\section{INTRODUCTION}

Radiocarbon concentration $\left(\Delta^{14} \mathrm{C}\right)$ and light stable isotopes $\left(\delta^{2} \mathrm{H}, \delta^{13} \mathrm{C}, \delta^{18} \mathrm{O}\right)$ in annual tree rings (especially in pine and oak from moderate climate zones) are sensitive indicators of climate changes (temperature, precipitation, and insolation), but also reflect anthropogenic influences. $\Delta^{14} \mathrm{C}$ values, as well as $\delta^{13} \mathrm{C}$ in tree rings over the last $150 \mathrm{yr}$, record the Suess effect (Pawełczyk and Pazdur 2004; Rakowski et al. 2004a,b, 2005). A major correlation between the $\delta^{13} \mathrm{C}$ ratio and temperature and a minor correlation between the $\delta^{13} \mathrm{C}$ ratio and precipitation have been identified (Pawełczyk et al. 2004; Szczepanek et al. 2006). The influence of temperature on $\delta^{13} \mathrm{C}$ in tree rings during the time of the Maunder minimum was described previously by Pazdur et al. (2005). Explicit correlations between ${ }^{14} \mathrm{C}$ concentration and sunspot numbers (Miyahara et al. 2004) and between $\Delta^{14} \mathrm{C}$ and $\delta^{13} \mathrm{C}$ are observed during times of climatic cooling.

Studies of climate change using carbon isotopes were continued in $\alpha$-cellulose samples extracted from annual tree rings of a pine collected from northeastern Poland (Suwałki region) and from a pine and an oak (latewood) collected from southern Poland (Niepołomice Forest) as a part of the ISONET project ("400 years of Annual Reconstructions of European Climate Variability Using a High-Resolution Isotopic Network"). Both regions vary in climatic conditions; the influence of the oceanic climate is significant in the southern part of the country, and the continental climate influences the northeastern part.

${ }^{14} \mathrm{C}$ concentration was measured on the whole wood or $\alpha$-cellulose extracted from samples of pine (1860-2003) using both accelerator mass spectrometry (AMS) and liquid scintillation spectrometry (LSC). The records of $\delta^{13} \mathrm{C}$ in $\alpha$-cellulose extracted from pines growing in northeastern and southern Poland and records of $\delta^{13} \mathrm{C}$ in $\alpha$-cellulose from oak latewood from the southern part of Poland over the last $400 \mathrm{yr}$ are presented along with the climate change indicators and the variation of atmospheric $\Delta^{14} \mathrm{C}$ values in the Northern Hemisphere $(\mathrm{NH})$ zone 1 (Hua and Barbetti 2004).

\footnotetext{
${ }^{1}$ Department of Radioisotopes, Institute of Physics, Silesian University of Technology, Krzywoustego 2, 44-100 Gliwice, Poland.

${ }^{2}$ Corresponding author. Email: anna.pazdur@polsl.pl.

${ }^{3}$ Nagoya University, Center for Chronological Research, Nagoya, Japan.
} 
The magnitude of the regional Suess effect in Poland was estimated over the last several decades and compared with values in other sites worldwide.

\section{SITES AND METHODS}

\section{Sites and Trees}

Figure 1 shows the location of the investigated sites in Poland. The new ${ }^{14} \mathrm{C}$ and ${ }^{13} \mathrm{C}$ results presented in this paper have been derived from Pinus sylvestris L. and Quercus robur L. (Niepołomice Forest, southern Poland) and Pinus sylvestris L. (Suwałki region, NE Poland). Results from other sites published previously are relevant to this work and given in Table 1 . The Niepołomice Forest covers $\sim 110 \mathrm{~km}^{2}$ and is located $\sim 20 \mathrm{~km}$ from the relatively large city of Kraków and the Nowa Huta steelworks. Because of their location, relatively strong anthropogenic influences were expected for the Niepołomice and Kraków sites, at least for the period when Nowa Huta was operating. Northeastern Poland is an area of many lakes and forests with little industry. In this area, the anthropogenic $\mathrm{CO}_{2}$ emission originates mainly from heating and transport, and its influence on the carbon isotope composition of tree rings should be insignificant. The Nagoya (Japan) and Ruda Śląska (southern Poland) sites are influenced by large cities and strong industrial activity, while Arequipa (Peru) is a small city with little industry, so the anthropogenic influence is expected to be limited to heating and road transport.

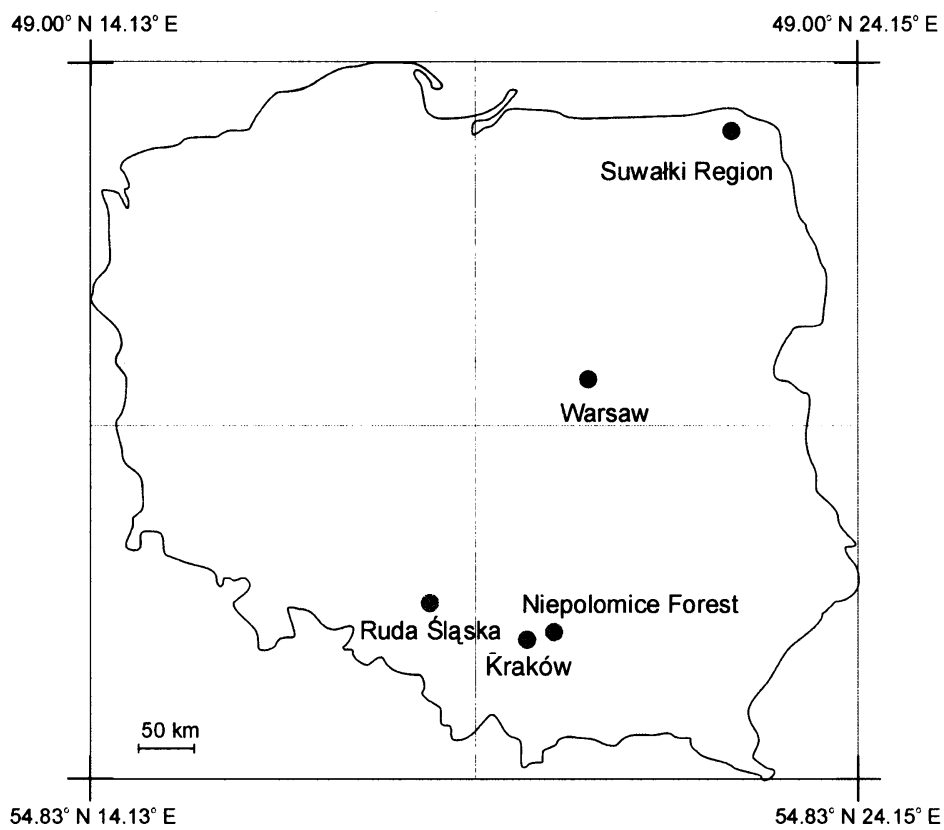

Figure 1 Map of the Polish tree sites investigated with respect to the Suess effect and climatic implications in the ${ }^{13} \mathrm{C}$ and ${ }^{14} \mathrm{C}$ composition of tree rings.

\section{Dendrochronology}

For the last $400 \mathrm{yr}$, high-resolution $(1 \mathrm{yr})$ records of $\Delta^{14} \mathrm{C}$ and $\delta^{13} \mathrm{C}$ changes were obtained with an absolute timescale determined by dendrochronology (Krąiec 1998; Szychowska-Krąpiec and Krąpiec 2005). Dendrochronological studies of pine and oak from southern Poland (Niepołomice 
Forest) and of pine from NE Poland (Suwałki region, see Figure 1) were conducted according to the standard methods (Fritts 1976; Esper et al. 2003; Helama et al. 2004) adopted for the ISONET project. Three chronologies were developed: PSPNF (Pinus sylvestris, Niepołomice Forest, Poland), QRPNF (Quercus robur, Niepołomice Forest, Poland), and PSPSR (Pinus sylvestris, Suwałki region, Poland). Isotope records from other sites, investigated earlier within other projects, were used for comparison-these included Kraków and Ruda Śląska in Poland (see Figure 1; Rakowski et al. 2001, 2005), Nagoya A and B from Japan (Rakowski et al. 2005, 2006), and the Arequipa site (Peru) (Rakowski et al. 2006). These chronologies were prepared by counting annual tree rings without reference to master chronologies for each of those regions.

\section{Sampling for Isotope Studies}

As part of the ISONET project, pine and oak trees at the Niepołomice Forest site and Suwałki region site were sampled for dendrochronological and stable isotope studies covering the last $400 \mathrm{yr}$. However, it was difficult to find such old trees in those areas. Samples of tree rings for the younger period (about the last $200 \mathrm{yr}$ ) were taken from living trees using a hollow drill, and the older period was covered by samples of ancient wood from old buildings (churches, abbeys, schools, etc.; Pazdur et al. 2005; Szychowska-Krąpiec and Krapiec 2005). Cores (or slices) from 4 different trees were dendrochronologically dated, and annual tree rings (whole growth rings for pine and latewood for oak) were mixed and homogenized for $\alpha$-cellulose extraction and stable isotope analyses.

\section{Alpha-Cellulose Extraction and Isotope Measurements}

The extraction of $\alpha$-cellulose was conducted using a method described by Green (1963). In our modified method, an ultrasonic bath was used to expedite the separation of single cellulose fibers from wood samples, and thus to increase the penetration of reagents (Loader et al. 1997; Pazdur et al. 2005). The $\delta^{13} \mathrm{C}$ measurements were made on a dual-inlet, triple collector mass spectrometer (significantly modified MI-1305 type) and dual-inlet system, DELTA ${ }^{\text {plus }}$ XP, via a conflow interface (Thermo Finnigan, Bremen, Germany).

Graphite targets for AMS measurement were prepared in the Gliwice Radiocarbon Laboratory from $\alpha$-cellulose samples extracted from Niepołomice Forest pine tree rings and measured at the AMS facility at the Centre for Chronological Research (HVEE 2.5MV, Nagoya University, Japan). Benzene for LSC counting was produced from whole wood samples of pine from the Suwałki region and measured using a Quantulus $1220^{\mathrm{TM}}$ in the Gliwice Radiocarbon Laboratory. Already published $\Delta^{14} \mathrm{C}$ results used for comparison of the Suess effect for different sites have been measured using both AMS (Nagoya A and B, Arequipa, and Kraków) and LSC (Augustów and Ruda Śląska) (see Table 1).

\section{SUESS EFFECT}

Figure 2 shows the emission of $\mathrm{CO}_{2}$ into the atmosphere from fossil fuel combustion for the regions investigated (after Marland et al. 2005). Increasing $\mathrm{CO}_{2}$ emissions began about $\mathrm{AD} 1850$ and are observed globally and for all investigated regions between 1850-2003. The trees are sensitive bioindicators of changes in $\mathrm{CO}_{2}$ emitted into the atmosphere, and ${ }^{14} \mathrm{C}$ measurements in tree rings may trace this in industrial areas (Rakowski et al. 2001, 2005, 2006; Pawełczyk and Pazdur 2004). Changes in $\Delta^{14} \mathrm{C}$ caused by the emission of $\mathrm{CO}_{2}$ into the atmosphere (the so-called Suess effect; Suess 1955) on the background, which is influenced by the effects of natural change and nuclear weapon tests, have been observed (Stuiver et al. 1998; Hua and Barbetti 2004; see Figures 3 and 4). 


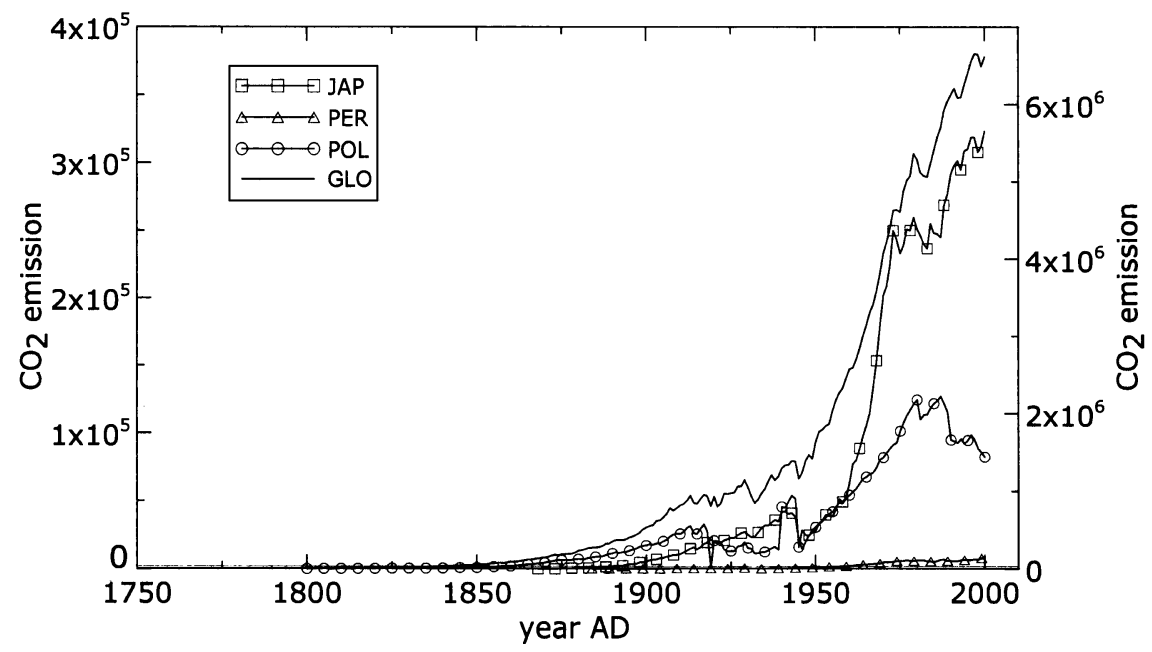

Figure 2 Regional (left scale) and global (right scale) emission of $\mathrm{CO}_{2}$ into the atmosphere from the fossil fuel combustion in thousands of metric tons of carbon (according to Marland et al. 2005). The curves present an estimation of the $\mathrm{CO}_{2}$ emission for the countries discussed in this paper: JAP = Japan; PER = Peru; POL = Poland; and GLO = global change.

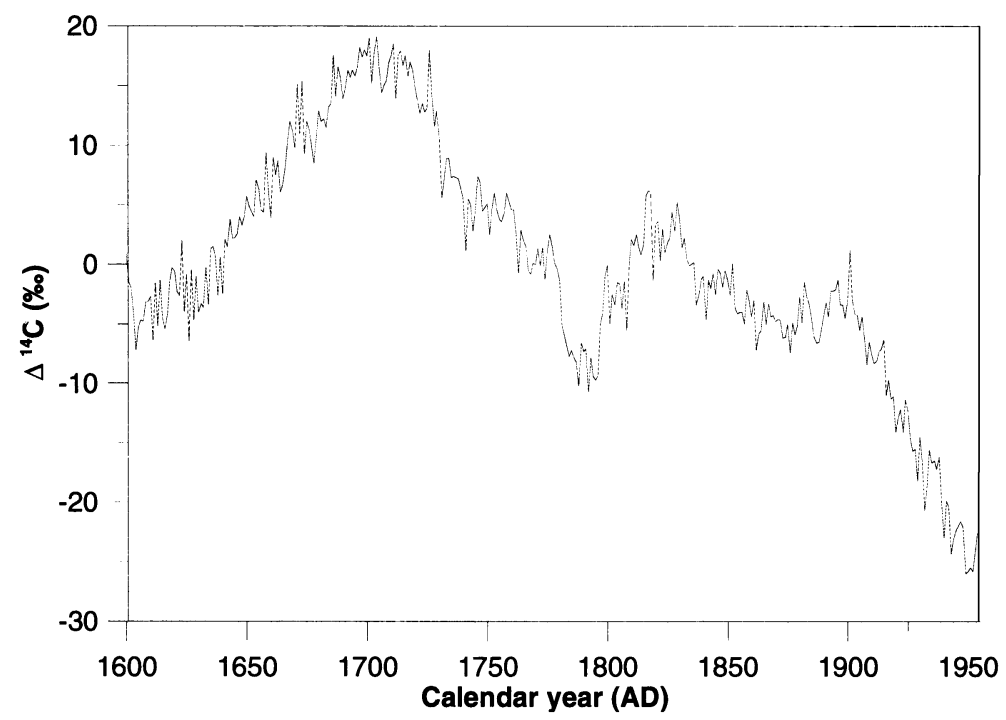

Figure $3 \Delta^{14} \mathrm{C}$ in tree rings (AD 1600-1954; Stuiver et al. 1998) as background used for calculation of ${ }^{14} \mathrm{~S}$ in pine tree rings from the Suwałki region.

As an indicator of the Suess effect, the value of ${ }^{14} \mathrm{~S}$ defined by Equation 1 can be used (Rakowski et al. 2001):

$$
{ }^{14} S=\frac{\Delta^{14} C_{B G}-\Delta^{14} C}{\Delta^{14} C_{B G}+1000} \times 100 \%
$$

where $\Delta^{14} C_{B G}$ and $\Delta^{14} C$ (Stuiver and Polach 1977) are values for clean air (without local Suess effect; Hua and Barbetti 2004) and in the local area, respectively. 


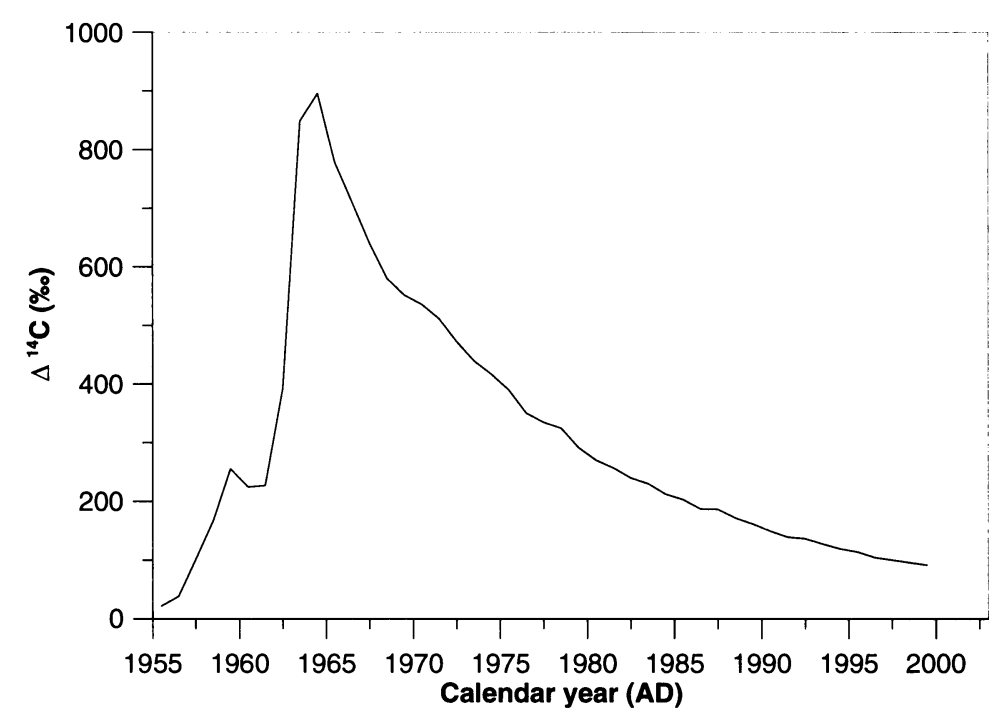

Figure 4 The summer $\Delta^{14} \mathrm{C}$ in atmospheric $\mathrm{CO}_{2}$ (AD 1955-2003; Hua and Barbetti 2004) as background for the calculation of ${ }^{14} \mathrm{~S}$ in pine tree rings from Niepołomice Forest.

Results of $\Delta^{14} \mathrm{C}$ measurements in the pine tree rings from the Suwałki region (Augustów site, Pawełczyk and Pazdur 2004) and Niepołomice Forest on the "background of clean air" are shown in Figures 5 and 6.

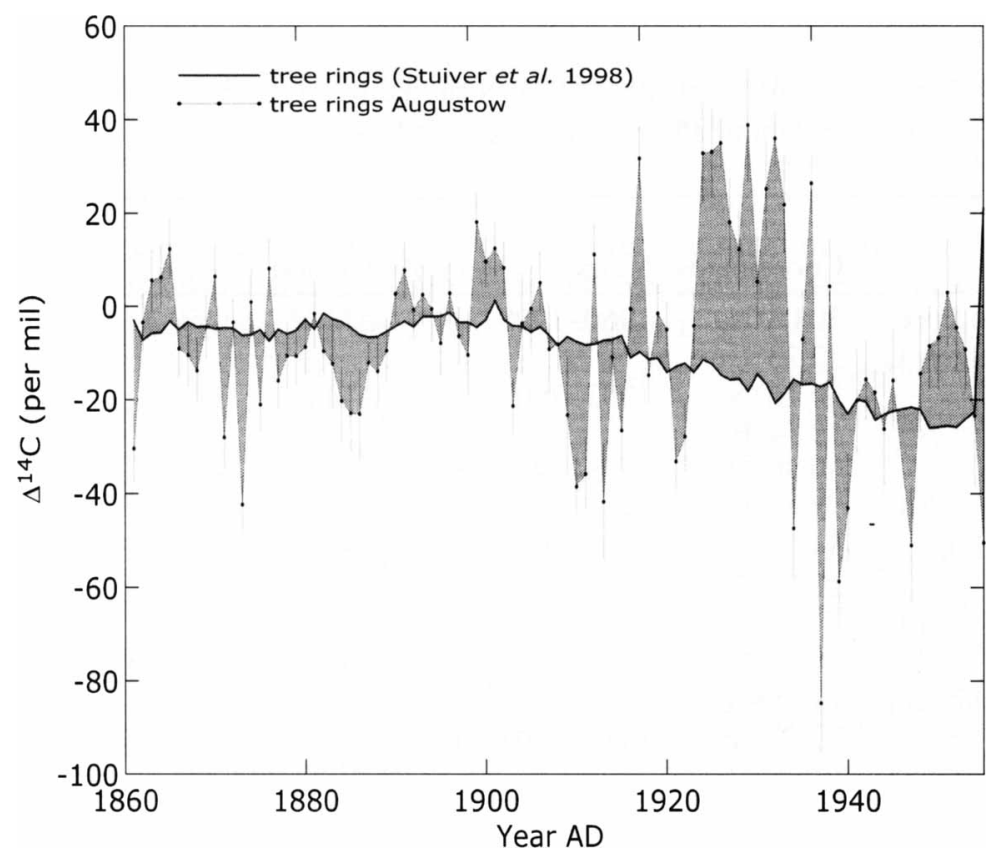

Figure $5 \Delta^{14} \mathrm{C}$ in whole wood of Pinus sylvestris L. tree rings from the Suwałki region (Augustów) and clean air as background (Stuiver et al. 1998) for AD 1861-1957. 


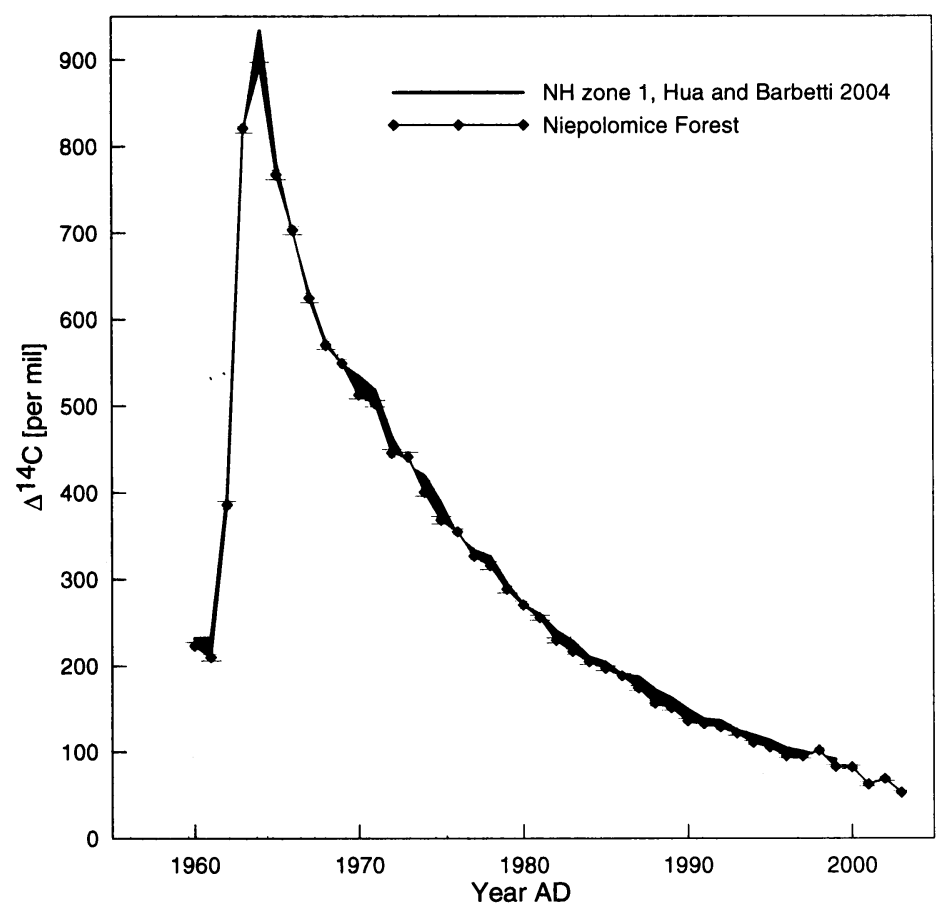

Figure $6 \Delta^{14} \mathrm{C}$ in $\alpha$-cellulose of Pinus sylvestris L. tree rings from Niepołomice Forest and in clean air as background for NH zone 1 (Hua and Barbetti 2004) for AD 1960-1980.

Table $1{ }^{14} \mathrm{~S}$ values for the different sites. ${ }^{14} \mathrm{C}$ measurements were made in whole wood of pine tree rings, except for the Niepołomice Forest site, where AMS* measurements using $\alpha$-cellulose were made.

\begin{tabular}{|c|c|c|c|c|c|c|}
\hline Site/tree & Coordinates & Years & $\begin{array}{l}\text { Res. } \\
(y r)^{\mathrm{a}}\end{array}$ & Method & ${ }^{14} \mathrm{~S}(\%)$ & Ref. \\
\hline $\begin{array}{l}\text { Niepołomice Forest } \\
\text { Pinus sylvestris L. }\end{array}$ & $\begin{array}{l}50.03^{\circ} \mathrm{N} \\
20.23^{\circ} \mathrm{E}\end{array}$ & 1960-1999 & 1 & AMS* & $0.60 \pm 0.65$ & $\begin{array}{l}\text { Hua and } \\
\text { Barbetti } 2004^{b}\end{array}$ \\
\hline $\begin{array}{l}\text { Kraków } \\
\text { Pinus sylvestris L. }\end{array}$ & $\begin{array}{l}50.16^{\circ} \mathrm{N} \\
19.54^{\circ} \mathrm{E}\end{array}$ & 1983-2002 & 1 & AMS & $3.63 \pm 0.27$ & $\begin{array}{l}\text { Rakowski } \\
\text { et al. } 2005\end{array}$ \\
\hline $\begin{array}{l}\text { Ruda Śląska } \\
\text { Pinus sylvestris L. }\end{array}$ & $\begin{array}{l}50.30^{\circ} \mathrm{N} \\
18.42^{\circ} \mathrm{E}\end{array}$ & 1965-1995 & 5 & LSC & $3.64 \pm 0.7$ & $\begin{array}{l}\text { Rakowski } \\
\text { et al. } 2001\end{array}$ \\
\hline $\begin{array}{l}\text { Suwałki region } \\
\text {-Augustów } \\
\text { Pinus svlvestris L. }\end{array}$ & $\begin{array}{l}54.10^{\circ} \mathrm{N} \\
22.93^{\circ} \mathrm{E}\end{array}$ & $1861-1958$ & 1 & LSC & $-0.47 \pm 3.76$ & $\begin{array}{l}\text { Pawełczyk and } \\
\text { Pazdur 2004c }\end{array}$ \\
\hline $\begin{array}{l}\text { Nagoya A } \\
\text { Pinus densiflora L. }\end{array}$ & $\begin{array}{l}35.57^{\circ} \mathrm{N} \\
136.58^{\circ} \mathrm{E}\end{array}$ & 1956-2002 & 1 & AMS & $3.44 \pm 0.20$ & $\begin{array}{l}\text { Rakowski } \\
\text { et al. } 2006\end{array}$ \\
\hline $\begin{array}{l}\text { Nagoya B } \\
\text { Pinus densiflora L. }\end{array}$ & $\begin{array}{l}35.57^{\circ} \mathrm{N} \\
136.58^{\circ} \mathrm{E}\end{array}$ & 1985-2003 & 1 & AMS & $3.61 \pm 0.31$ & $\begin{array}{l}\text { Rakowski } \\
\text { et al. } 2005\end{array}$ \\
\hline $\begin{array}{l}\text { Arequipa } \\
\text { Pinus radiata } \mathrm{L} .\end{array}$ & $\begin{array}{l}16.23^{\circ} \mathrm{S} \\
73.31^{\circ} \mathrm{W}\end{array}$ & 1986-2001 & 1 & AMS & $0.79 \pm 0.17$ & $\begin{array}{l}\text { Rakowski } \\
\text { et al. } 2006\end{array}$ \\
\hline
\end{tabular}

${ }^{\mathrm{a}}$ Res. $(\mathrm{yr})=$ time resolution.

${ }^{b}$ The measurements were performed for the years $1960-2003$, but ${ }^{14} \mathrm{~S}$ values were calculated for the period covered by Hua and Barbertti (2004).

${ }^{c}$ The results of ${ }^{14} \mathrm{C}$ measurements were published by Pawełczyk and Pazdur (2004). 
The average ${ }^{14} \mathrm{~S}$ values, obtained from data presented in Figures 5-6, are given in Table 1. Additionally, ${ }^{14} \mathrm{~S}$ values from sites investigated by Rakowski et al. $(2001,2005,2006)$ are presented. A comparison of ${ }^{14} \mathrm{~S}$ values indicates the regions with small positive values (clean areas) (Niepołomice Forest and the Suwałki region in Poland and Arequipa in Peru). Sites where trees were growing in urban areas (Kraków, Poland and Nagoya, Japan) have much higher ${ }^{14} \mathrm{~S}$ values. The ${ }^{14} \mathrm{~S}$ values for clean areas and urban areas with high emissions of $\mathrm{CO}_{2}$ into the atmosphere are similar in Europe, Asia, and South America.

\section{${ }^{13} \mathrm{C}$ AND ${ }^{14} \mathrm{C}$ IN TREE RINGS FROM SOUTHERN AND NE POLISH SITES}

\section{Correlation of $\delta^{13} \mathrm{C}$ with Meteorological Data}

Carbon stable isotope variations within tree rings may provide valuable information on past climatic changes. Photosynthesis converts $\mathrm{CO}_{2}$ in the atmosphere to carbohydrates. Because tree cellulose is formed from carbon acquired through photosynthesis, its stable isotope ratio reflects that of the atmosphere. Although the carbon atoms of cellulose come from atmospheric $\mathrm{CO}_{2}$, the $\delta^{13} \mathrm{C}$ value of cellulose is not the same as that of atmospheric $\mathrm{CO}_{2}$ (Craig 1954; Wickman 1956; Park and Epstein 1960; Deines 1980). The processes controlling isotopic fractionation in trees are not fully explained yet. However, one of the widely used models explaining changes in the isotopic compositions of tree rings was developed by Francey and Farquhar (1982).

In the case of pine from Augustów (Suwałki region) for the years 1899-1968, high correlation coefficients between values of $\delta^{13} \mathrm{C}$ in latewood $\alpha$-cellulose and average temperature exist for July $(r=$ $0.41, n=70, p<0.001)$ and August $(r=0.39, n=70, p<0.001)$, i.e. for months of latewood formation. The correlation coefficient between $\delta^{13} \mathrm{C}$ in latewood $\alpha$-cellulose and precipitation in the period of July and August for AD 1922-1948 is -0.33 ( $n=27, p<0.1)$ (Pawełczyk et al. 2004).

Independent investigations of trees from the Suwałki region and Niepołomice Forest were conducted as part of the European project ISONET (see Acknowledgments). For calculations, the detrended and raw values of $\delta^{13} \mathrm{C}$ were used. For the Suwałki region for the period AD 1899-1968, the correlation coefficient due to temperature is $r=0.38$ for August $(n=73, p<0.001)$ and the correlation coefficient due to precipitation is $r=-0.35$ for the same month $(n=73, p<0.01)$. If periods combined from several months were taken into account, higher correlation coefficients would be obtained; for example, for the period May-August, the correlation coefficient due to temperature is 0.54 ( $n=73, p<0.001)$; while for June-August, the correlation coefficient due to precipitation is $-0.40(n=73, p<0.001)$. Thus, it is possible to state that changes of ${ }^{13} \mathrm{C}$ in tree rings may reflect changes of temperature during the summer for the ecologically clean region (Pawełczyk S, Pazdur A, Boettger T, Haupt M, Krąpiec M, Szychowska-Krąpiec E, unpublished data).

The Niepołomice Forest results suggest that climatic signals for regions affected by human impact are not as clear as in regions unchanged by human activity (Szczepanek et al. 2006). In the case of the period AD 1901-2000, the highest significant values of correlation coefficients calculated between corrected $\delta^{13} \mathrm{C}$ in tree rings of oak and temperature is 0.21 for September $(n=100, p<0.05)$. A significant correlation coefficient was found between $\delta^{13} \mathrm{C}$ in tree rings of pine and the increased sunlight in June $(r=0.35, n=100, p<0.001)$.

\section{Comparison of $\delta^{13} \mathrm{C}$ and ${ }^{14} \mathrm{~S}$}

Comparison of $\delta^{13} \mathrm{C}$ and ${ }^{14} \mathrm{~S}$ in $\alpha$-cellulose between pine and oak tree rings from Niepołomice Forest and $\delta^{13} \mathrm{C}$ in $\alpha$-cellulose and ${ }^{14} \mathrm{~S}$ in whole wood of pine from the Suwałki region are presented in 
Figures 7 and 8, respectively. Between AD 1861-1958 (in the Suwałki region) and 1960-1999 (in the Niepołomice Forest), no correlations between $\delta^{13} \mathrm{C}$ and ${ }^{14} \mathrm{~S}$ with high confidence levels (see $r$ and $p$ values in the figure captions) are visible. Low ${ }^{14} \mathrm{~S}$ values for these 2 sites (see Table 1) along with modeling of anthropogenic effects (Sżczepanek et al. 2006; Pawełczyk S, Pazdur A, Boettger T, Haupt M, Krąpiec M, Szychowska-Krąpiec E, unpublished data) indicate those forest regions are clean areas where variations of $\delta^{13} \mathrm{C}$ and ${ }^{14} \mathrm{~S}$ caused by industrial influence are not expected.

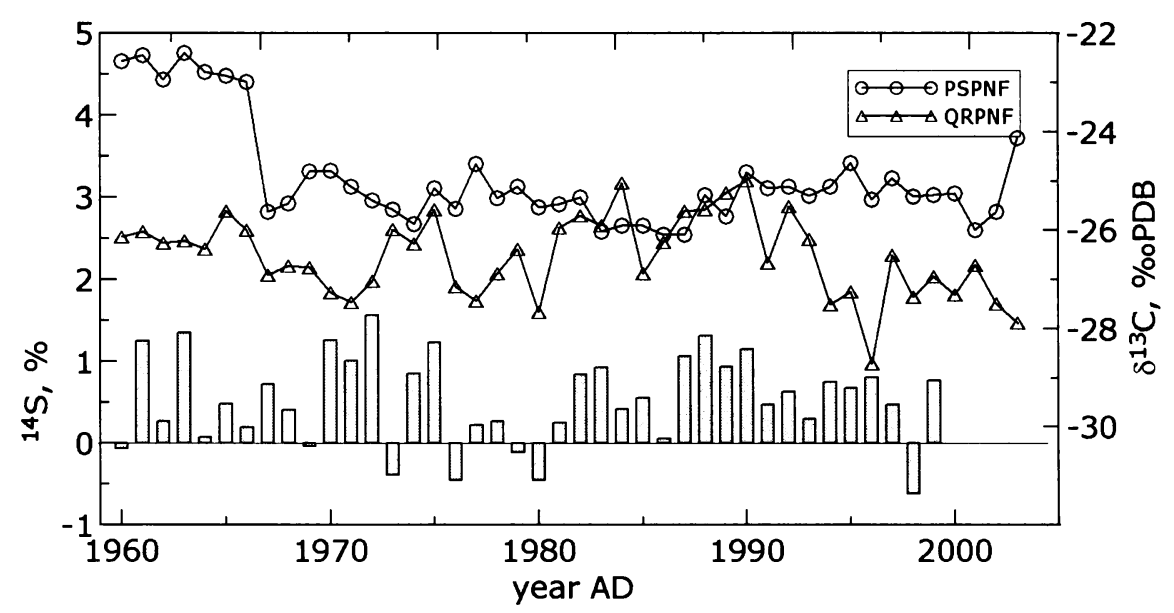

Figure 7 Comparison of $\delta^{13} \mathrm{C}$ of pine (PSPNF) and oak (QRPNF) from Niepołomice Forest with ${ }^{14} \mathrm{~S}$ from the PSPNF chronology for the period $1960-1999$. Correlations between ${ }^{14} \mathrm{~S}$ and $\delta^{13} \mathrm{C}$ were not significant (with PSPNF, $r=0.08, n=19, p<0.5$; with QRPNF, $r=0.1, n=19, p<0.5$ ).

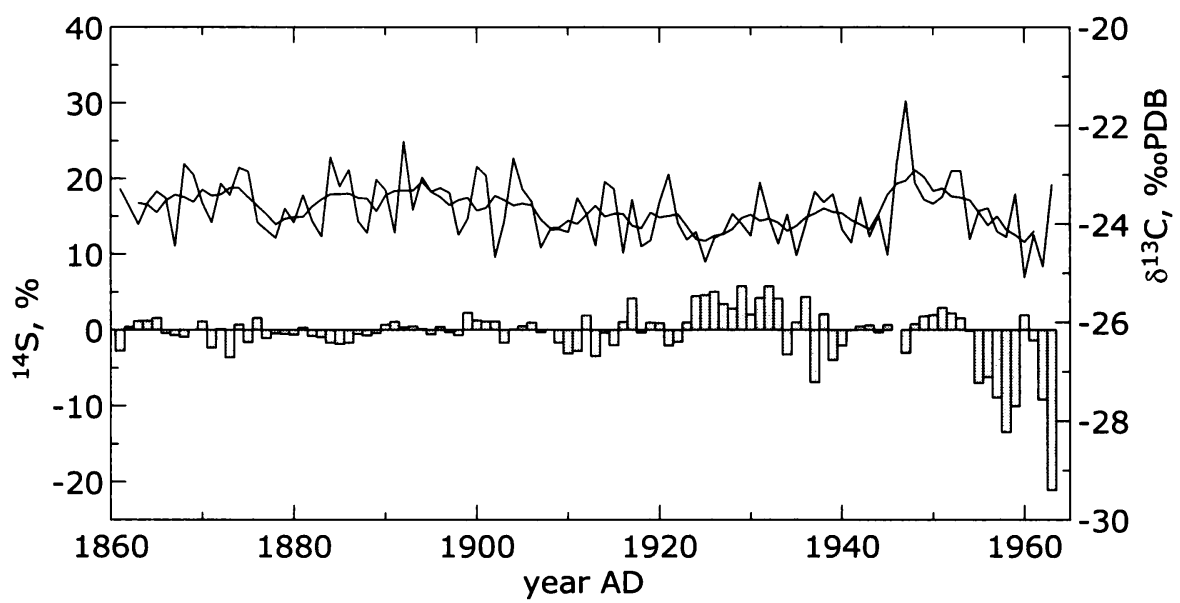

Figure 8 Comparison of $\delta^{13} \mathrm{C}$ and ${ }^{14} \mathrm{~S}$ in pine from the Suwałki region (PSPSR) in the period 1861-1958. The correlation coefficient is $r=0.12(102$ points, $p<0.3)$; the mean value of ${ }^{14} \mathrm{~S}=-0.47 \pm 3.76$.

\section{${ }^{13} \mathrm{C}$ AND ${ }^{14} \mathrm{C}$ DURING THE PERIODS OF MAUNDER AND DALTON MINIMA}

High-resolution ( $1 \mathrm{yr}) \delta^{13} \mathrm{C}$ records in $\alpha$-cellulose from pine whole wood (Niepołomice Forest, PSPNF; and Suwałki region, PSPSR chronologies) and oak latewood (Niepołomice Forest, QRPNF chronology) were investigated within the period $1600-2003$ as part of the ISONET project. $\delta^{13} \mathrm{C}$ 
results obtained for the period between 1600 (or 1627) and 1954, before the rapid change of ${ }^{14} \mathrm{C}$ concentration caused by the nuclear weapon tests, were compared with the $\Delta^{14} \mathrm{C}$ record (Stuiver et al. 1998) and sunspot numbers (Stuiver and Braziunas 1993). Throughout most of this investigated period, the $3 \delta^{13} \mathrm{C}$ records show a decreasing trend (see Figure 9). If we assume a positive correlation between $\delta^{13} \mathrm{C}$ and temperature determined by the physiology of trees (Robertson et al. 1997; Pawełczyk et al. 2004), observed trends can be interpreted as a record of a decrease of annual (records in pine) and summer (records in oak) temperatures.

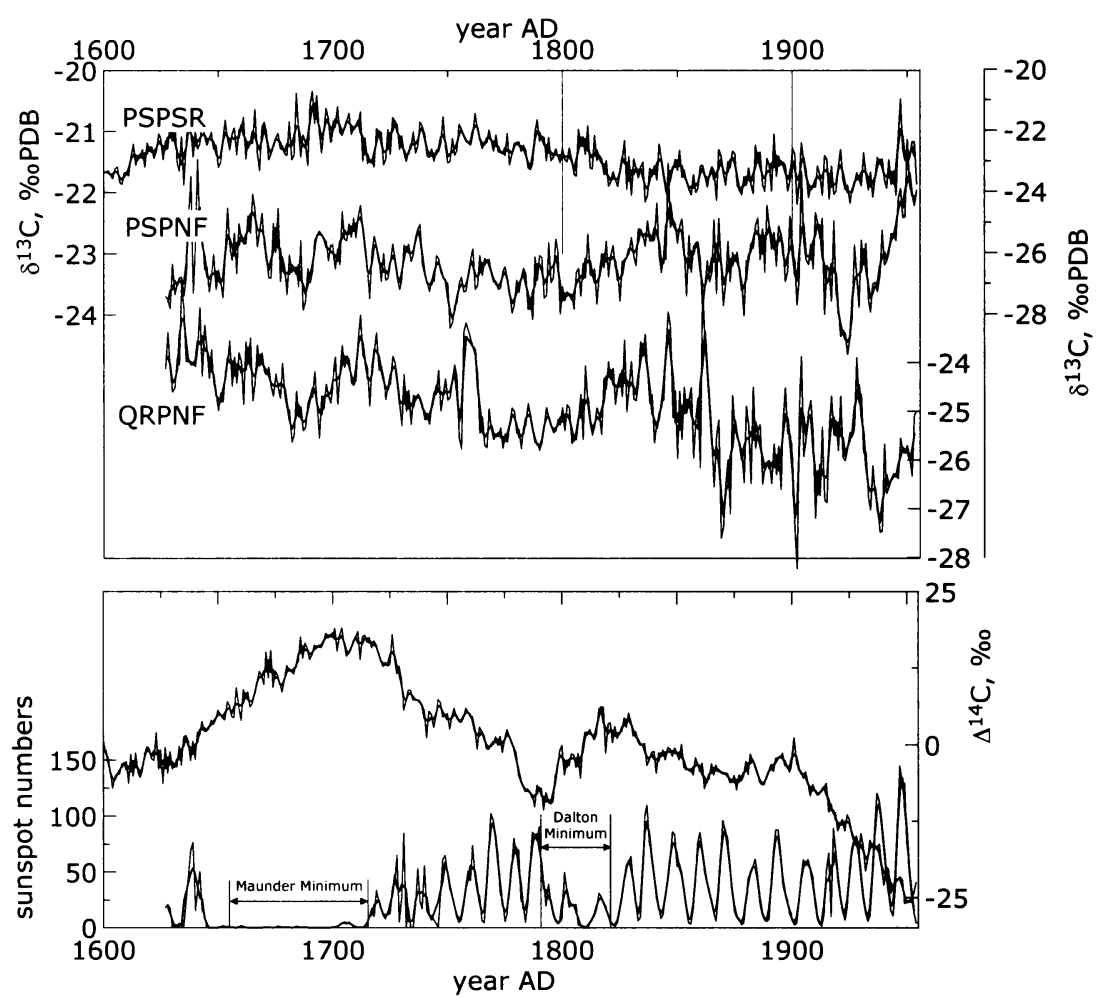

Figure 9 Changes of $\delta^{13} \mathrm{C}, \Delta^{14} \mathrm{C}$, and sunspot numbers in tree rings. $\delta^{13} \mathrm{C}$ values for the PSPNF (pine) and QRPNF (oak) chronologies (1627-1954) from Niepołomice Forest and the PSPSR (pine) chronology (1600-1954) from the Suwałki region. $\Delta^{14} \mathrm{C}$ (Stuiver et al. 1998) and sunspot number (Stuiver and Braziunas 1993) records cover the period 1600-1954. A 3-yr running average is plotted over yearly variations of the $\delta^{13} \mathrm{C}$ and $\Delta^{14} \mathrm{C}$ records.

The first observation of $\delta^{13} \mathrm{C}$ in $\alpha$-celullose of oak latewood from Niepołomice Forest, $\Delta^{14} \mathrm{C}$, and sunspot numbers was described by Pazdur et al. (2005). Variations of ${ }^{14} \mathrm{C}$ content in $\sim 700$-yr-old cedar tree rings growing in Japan, during the Spörer minimum (1415-1537), were observed recently by Miyahara et al. (2004).

${ }^{13} \mathrm{C}$ and ${ }^{14} \mathrm{C}$ isotope records during the Maunder minimum (1645-1715) in tree rings of pine and oak (PSPNF, PSPSR, and QRPNF chronologies) are presented in Figure 10. Superimposed on the annual $\delta^{13} \mathrm{C}$ and $\Delta^{14} \mathrm{C}$ curves are $10-\mathrm{yr}$ running averages. The middle of the Maunder minimum period is $\mathrm{AD} 1680$. A comparison between the $\delta^{13} \mathrm{C}$ values for all records and sunspot numbers around this year shows a strong positive correlation between them, which can be interpreted as climatic (temperature) changes upon $\delta^{13} \mathrm{C}$ values. For ${ }^{14} \mathrm{C}$, as a cosmogenic isotope with high produc- 

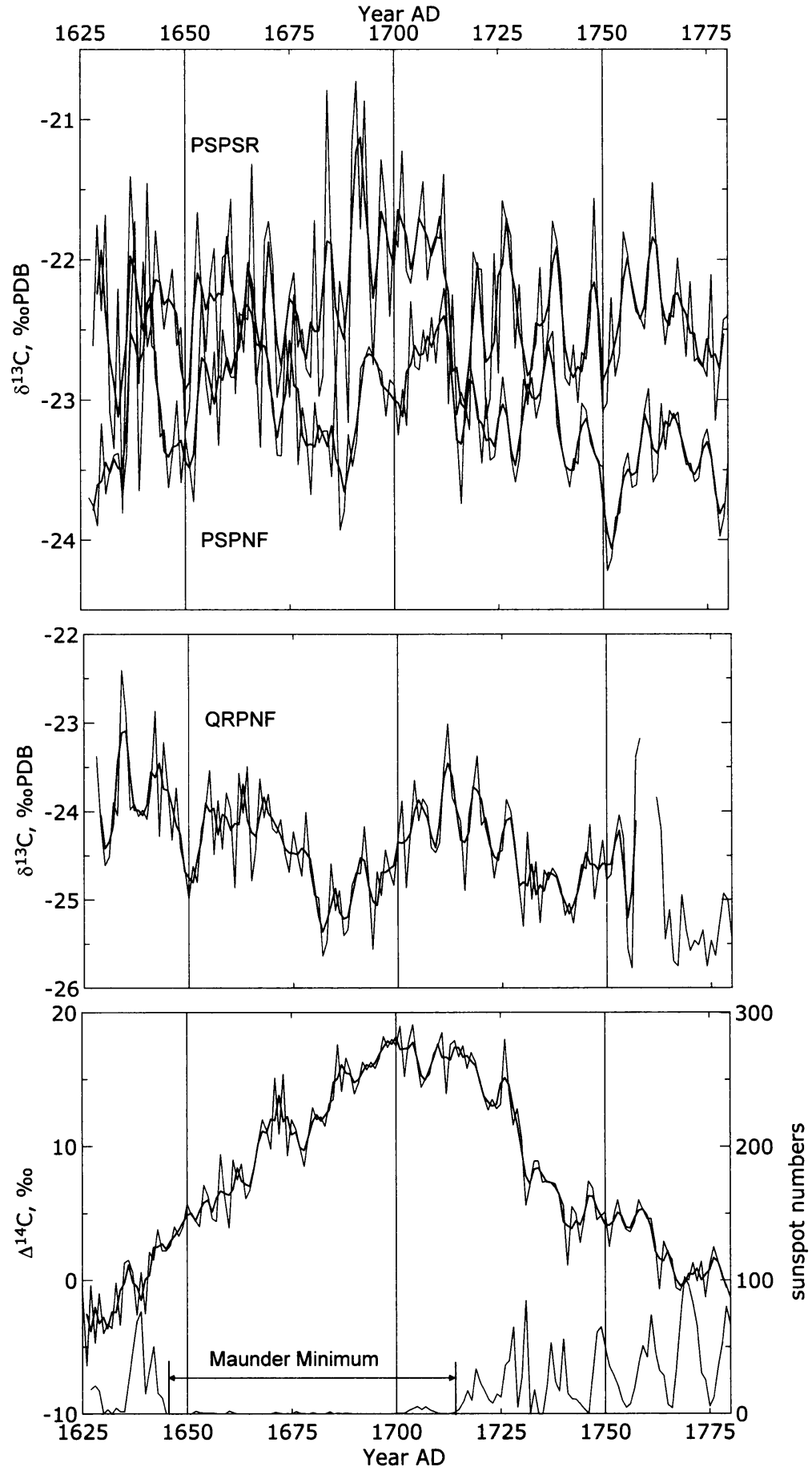

Figure $10 \delta^{13} \mathrm{C}$ and $\Delta^{14} \mathrm{C}$ around the Maunder minimum (1645-1715) in tree rings of pine (PSPNF and PSPSR) and oak (QRPNF). The 3-yr running averages are also shown. 
tion rate during the time of low sun activity, a negative correlation between $\Delta^{14} \mathrm{C}$ and sunspot numbers, and between $\Delta^{14} \mathrm{C}$ and $\delta^{13} \mathrm{C}$ in tree rings, can be expected. Such a correlation was observed for oak from Niepołomice Forest, with a correlation coefficient of $r=-0.51$, when the $\Delta^{14} \mathrm{C}$ was shifted by $30 \mathrm{yr}$ for $10-\mathrm{yr}$ average values of $\Delta^{14} \mathrm{C}$ and $\delta^{13} \mathrm{C}$ in a single tree (Pazdur et al. 2005).

In this study, a negative correlation between $\Delta^{14} \mathrm{C}$ and $\delta^{13} \mathrm{C}$ can be obtained by shifting the $\Delta^{14} \mathrm{C}$ record towards older ages by $24 \mathrm{yr}$ in the timescale from 1669 to 1645 and from 1739 to 1715 . The correlation coefficients between shifted $\Delta^{14} \mathrm{C}$ and $\delta^{13} \mathrm{C}$ values in the Maunder minimum have negative values for PSPNF and QRPNF chronologies (SE Poland), and this is not significant for the PSPSR chronology (NE Poland, see Table 2). Significant correlation for PSPSR $(r=-0.31, p<0.01)$ can be obtained when the $\Delta^{14} \mathrm{C}$ is shifted by at least $38 \mathrm{yr}$. The difference of 14 yr between 2 sites may indicate that the cooling was earlier in NE Poland (Suwałki region) than in southern Poland (Niepołomice Forest).

Table 2 Correlations between $\Delta^{14} \mathrm{C}$ and $\delta^{13} \mathrm{C}$ in the time periods of the Maunder and Dalton minima. The limits of time periods of $\Delta^{14} \mathrm{C}$ for the calculation of correlation coefficients were shifted, and they are $24 \mathrm{yr}$ older in comparison to the limits of the Maunder and Dalton minima; $r=$ correlation coefficient; $n=$ number of points; $p=$ confidence level.

\begin{tabular}{lrcc|rcc}
\hline & \multicolumn{3}{c|}{ Unshifted } & \multicolumn{3}{c}{ Shifted } \\
\cline { 2 - 8 } Chronology & $r$ & $n$ & $p$ & $r$ & $n$ & $p$ \\
\hline Maunder minimum & & & & & & \\
QRPNF & -0.06 & 71 & $<0.7$ & -0.42 & 71 & $<0.001$ \\
PSPNF & 0.17 & 71 & $<0.2$ & -0.27 & 71 & $<0.01$ \\
PSPSR & 0.28 & 71 & $<0.02$ & -0.04 & 71 & $<0.7$ \\
Dalton minimum & & & & & & \\
QRPNF & 0.36 & 31 & $<0.05$ & -0.18 & 31 & $<0.4$ \\
PSPNF & 0.07 & 31 & $<0.7$ & -0.31 & 31 & $<0.1$ \\
PSPSR & -0.31 & 31 & $<0.1$ & 0.12 & 31 & $<0.5$ \\
\hline
\end{tabular}

Results from the comparison of records for different chronologies during the Dalton minimum (1790-1820) are shown in Figure 11. The minimum of the $\delta^{13} \mathrm{C}$ record for pine from NE Poland (PSPSR) is observed earlier than that for pine in southern Poland (PSPNF). On the other hand, the record for oak from Niepołomice Forest does not show a distinct minimum in the Dalton minimum period. Similar calculations as those obtained for the Maunder minimum (isotope composition of $\delta^{13} \mathrm{C}, \Delta{ }^{14} \mathrm{C}$ in tree rings, and sunspot numbers) were performed for the Dalton minimum and are included in Table 2. In contrast to the records for the Maunder minimum, obtaining similarly significant correlations for the Dalton minimum was not possible.

\section{CONCLUSION}

The results obtained in this study clearly show the correlation between the isotopic composition of carbon in annual tree rings and natural (temperature, solar activities, etc.) and anthropogenic factors (Suess effect, nuclear bomb tests).

The decreasing ${ }^{14} \mathrm{C}$ concentration due to the Suess effect for the different sites is shown using the ${ }^{14} \mathrm{~S}$ value. Similar low average values of ${ }^{14} \mathrm{~S}$ (about -0.4 to $0.8 \%$ ) were obtained for clean areas and high values (about 3.4-3.6\%) for industrial and/or urban areas in different locations. This is potentially a complementary method for monitoring the $\mathrm{CO}_{2}$ emission from fossil fuel combustion. Analysis of $\Delta^{14} \mathrm{C}, \delta^{13} \mathrm{C}$, and the sunspot numbers during the Maunder and Dalton minima indicate a delay of the 

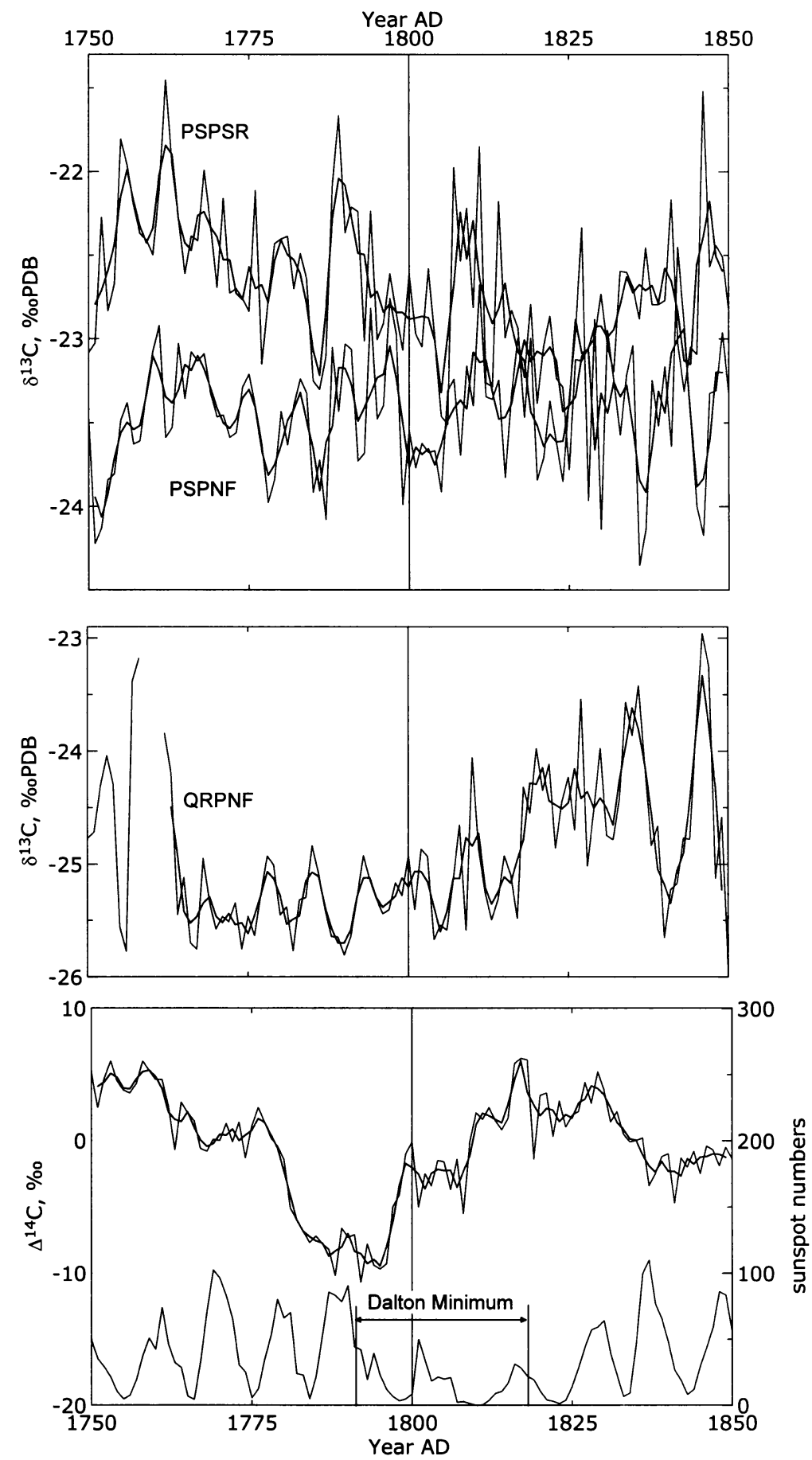

Figure $11 \delta^{13} \mathrm{C}$ and $\Delta^{14} \mathrm{C}$ during the Dalton minimum (1790-1820) in tree rings of pine (PSPNF and PSPSR) and oak (QRPNF). The 3-yr running average is also shown. 
${ }^{14} \mathrm{C}$ response to the rapid change in solar activity. A detailed analysis of the records with the use of more advanced statistical tools could help to calculate more precisely this delay and its significance.

\section{ACKNOWLEDGMENTS}

The results were obtained in of collaboration with the following international projects:

- ISONET (EVK2-CT-2002-00147, 2003-2006): 400 Years of Annual Reconstructions of European Climate Variability Using a High-Resolution Isotopic Network (FP5).

- GADAM (EVK2-CT-2002-80008, 2003-2006): Gliwice Absolute Dating Methods Centre of Excellence (Program FP5).

- Scholarship of Ministry of Education, Sciences, Sport and Culture of Japan (2001-2006).

- Archives of post-bomb ${ }^{14} \mathrm{C}$ signal. Sasagawa Foundation grant (2004-2005).

\section{REFERENCES}

Craig H. 1954. Carbon-13 in plants and the relationship between carbon-13 and carbon-14 variations in nature. Journal of Geology 62:115-49.

Deines P. 1980. The isotopic composition of reduced organic carbon. In: Fritz P, Fontes JC, editors. Handbook of Environmental Isotope Geochemistry. New York: Elsevier. p 329-406.

Esper J, Cook ER, Krusic PJ, Peters K, Schweingruber FH. 2003. Tests of the RCS method for preserving low-frequency variability in long tree-ring chronologies. Tree-Ring Research 59(2):81-98.

Francey RJ, Farquhar GD. 1982. An explanation of ${ }^{13} \mathrm{C} /$ ${ }^{12} \mathrm{C}$ variations in tree rings. Nature 297(5861):28-31.

Fritts HC. 1976. Tree Rings and Climate. London: Academic Press. 579 p.

Green JW. 1963. Wood cellulose. In: Whistler RL, editor. Methods of Carbohydrate Chemistry. New York: Academic Press. p 9-21.

Helama S, Lindholm M, Timonen M, Eronen M. 2004. Detection of climate signal in dendrochronological data analysis: a comparison of tree-ring standardization methods. Theoretical and Applied Climatology 79(3-4):239-54.

Hua Q, Barbetti M. 2004. Review of tropospheric bomb ${ }^{14} \mathrm{C}$ data for carbon cycle modeling and age calibration purposes. Radiocarbon 46(3):1273-98.

Krapiec M. 1998. Oak dendrochronology of the Neo-Holocene in Poland. Folia Quaternaria 69:5-133.

Loader NJ, Robertson I, Barker AC, Switsur VR, Waterhouse JS. 1997. An improved technique for the batch processing of small whole wood samples to $\alpha$-cellulose. Chemical Geology 136(3-4):313-7.

Marland G, Boden TA, Andres RJ. 2005. Global, regional, and national fossil fuel $\mathrm{CO}_{2}$ emissions. In: Trends: A Compendium of Data on Global Change. Carbon Dioxide Information Analysis Center, Oak Ridge National Laboratory, U.S. Department of Energy, Oak Ridge, Tennessee, USA.

Miyahara H, Masuda K, Furuzawa H, Menjo H, Muraki Y, Kitagawa H, Nakamura T. 2004. Variation of the ra- diocarbon content in tree rings during the Spoerer minimum. Radiocarbon 46(2):965-8.

Park R, Epstein S. 1960. Carbon isotope fractionation during photosynthesis. Geochimica et Cosmochimica Acta 21(1-2):110-26.

Pawełczyk S, Pazdur A. 2004. Carbon isotopic composition of tree rings as tool for biomonitoring $\mathrm{CO}_{2}$ level. Radiocarbon 46(2):701-19.

Pawełczyk S, Pazdur A, Hałas S. 2004. Stable carbon isotopic composition of tree rings from a pine tree from Augustów Wilderness, Poland, as temperature and local environment conditions indicator. Isotopes in Environmental and Health Studies 40(2):145-54.

Pazdur A, Korput S, Fogtman M, Szczepanek M, Hałas S, Krąpiec E, Szychowska-Krapiec E. 2005. Carbon13 in $\alpha$-cellulose of oak latewood (Jędrzejów, southern Poland) during the Maunder minimum. Geological Quarterly 49(2):165-72.

Rakowski AZ, Pawełczyk S, Pazdur A. 2001. Changes of ${ }^{14} \mathrm{C}$ concentration in modern trees from Upper Silesia region, Poland. Radiocarbon 43(2B):679-89.

Rakowski AZ, Kuc T, Nakamura T, Pazdur A. 2004a. Radiocarbon concentration in the atmosphere and modern tree rings in the Kraków area, southern Poland. Radiocarbon 46(2):911-6.

Rakowski AZ, Nakamura T, Pazdur A. 2004b. Changes in radiocarbon concentration in modern wood from Nagoya, central Japan. Nuclear Instruments and Methods in Physics Research B 223-224:507-10.

Rakowski AZ, Kuc T, Nakamura T, Pazdur A. 2005. Radiocarbon concentration in urban area. Geochronometria 24:63-8.

Rakowski AZ, Nakamura T, Pazdur A. 2006. Variations of anthropogenic $\mathrm{CO}_{2}$ in urban area deduced by radiocarbon concentration in modern tree rings. Poster \#166, 19th International Radiocarbon Conference, Oxford, United Kingdom, 3-7 April 2006.

Robertson I, Switsur VR, Carter AHC, Barker AC, Waterhouse JS, Briffa KR, Jones PD. 1997. Signal strength and climate relationships in ${ }^{13} \mathrm{C} /{ }^{12} \mathrm{C}$ ratios of 
tree ring cellulose from oak in east England. Journal of Geophysical Research 102(D16):19,507-16.

Stuiver M, Braziunas TF. 1993. Sun, ocean, climate and atmospheric ${ }^{14} \mathrm{CO}_{2}$ : an evaluation of causal and spectral relationships. The Holocene 3(4):289-305.

Stuiver M, Polach HA. 1977. Discussion: reporting of ${ }^{14} \mathrm{C}$ data. Radiocarbon 19(3):355-63.

Stuiver M, Reimer PJ, Braziunas TF. 1998. High-precision radiocarbon age calibration for terrestrial and marine samples. Radiocarbon 40(3):1127-51.

Suess HE. 1955. Radiocarbon concentration in modern wood. Science 122(3166):415-7.
Szczepanek M, Pazdur A, Pawełczyk S, Böttger T, Haupt M, Hałas S, Bednarz Z, Krąpiec M, SzychowskaKrąpiec E. 2006. Hydrogen, carbon and oxygen isotopes in pine and oak tree rings from southern Poland as climatic indicators in years 1900-2003. Geochronometria 25:67-76.

Szychowska-Krąpiec E, Krąpiec M. 2005. The Scots pine chronology (AD 1584-2004) for the Suwałki region (NE Poland). Geochronometria 24:41-52.

Wickman FE. 1956. Variations in the relative abundance of carbon isotope in plants. Geochimica et Cosmochimica Acta 2(4):243-54. 